\title{
Level of conscious- ness after cadaveric kidney transplant under halothane anaesthesia
}

Serum and urine bromide levels, serum morphine levels, and postoperative awakening times wero observed in 24 patients; I6 undergoing cadaveric kidney transplantation under halothane anaesthesia, eight without preanaesthetic medication (Group A) and eight with morphine preanassthetic medication (Group B), and eight patients (control) with normai kidney function scheduled for colon resection (Group C). Bromide levels were higher in patients after kidney transplant than in the control group. Transplani patients who did not receive morphine awak. ened faster after anaesthesia than patients who received $10 \mathrm{mg}$ of morphine 60 minutes before anaesthesia. Morphine levels at the end of anaesthesia were $145 \mu \mathrm{g}$. $100 \mathrm{ml}^{-1}$ in Group B; significanty higher than those found in patients with normal kidney function (Group $C$ ) (5 \pm 1.05$)$. The majority of the patients undergoing kidney transplantation and receiving morphine for premedication were fully awake 24 hours following surgery despite serum bromide levels of $158 \mu \mathrm{g} \cdot \mathrm{ml}^{-1}$. Control patients had higher awakening scores after surgery than patients in Group A, despite receiving $10 \mathrm{mg}$ of morphine as preoperative medication.

Serum bromide levels were far below $480 \mu \mathrm{g} \cdot \mathrm{ml}^{-1}$, the level required to produce clinical symptoms of bromism. The serum and urine bromide levels found in the patients after kidney transplant, even when higher than the control group, were not high enough to explain

From the Department of Anesthesiology, State University of New York, Downstate School of Medicine, Brookly'n, New York.

Address correspondence to: Pienc A. Casthcly MD, Department of Anesthesiology, Downstate Medical Center, 450 Clarkson Avenue, Box 6, Brooklyn, New York 11.203. the prolonged sleepiness found in these patients. The morphine given as preoperative medication may be one of the factors responsible for this finding. Other factors, such as decreased pratein binding, decreased albumin levels, abnormal blood brain barrier and brain function, and the degree of function of the transplanted kidney may account for the prolonged sleepiness found in patients receiving transplants.

\section{Key words}

ANAESTHETICS, vOLATILE: halothane; ANAESTHETICS, NARCOTIC: morphine; METABOLISM: halothane, bromide.

Halothane has enjoyed wide popularity as a primary volatile anaesthetic. Fifteen to twenty per cent of inspired halothane is metabolized and active metabolites can be detected in the blood for up to 14 days. ${ }^{\mathrm{l}-3}$ Dehalogenation occurs first in this biotransformation pathway and eventually yields trifluoroacetic acid, bromide, and chloride. ${ }^{4-8}$

Bromide concentrations greater than $480 \mu \mathrm{g} \mathrm{ml}^{-1}$ produce central nervous system (CNS) symptons such as drowsiness, lethargy, and headaches. Electroencephalographic (EEG) changes accompany the intoxication. We have frequently seen prolonged recovery following halothane anaesthesia in patients with end-stage renal failure undergoing kidney transplantation which could not be explained by residual anaesthesia.

The purpose of this study was to measure urine and serum bromide levels, and serum morphine levels before and after halothane anaesthesia in patients who received cadaveric kidney transplants and in a control group, and to correlate these levels with postoperative levels of consciousness. 
Methods

Informed consent was obtained from 24 patients 16-48 years of age scheduled for kidney transplant or colon resection. The transplant patients were randomly divided into two groups. Group A consisted of eight patients in end-stage renal failure scheduled for kidney transplantation who were given no preoperative medication. Group B included eight patients in end-stage renal failure who were given $10 \mathrm{mg}$ of morphine 60 minutes prior to induction of general anaesthesia. Eight patients with normal kidney function scheduled for colon resection who were given $10 \mathrm{mg}$ of morphine as preoperative medication served as a control group (Group C). No other doses of morphine were administered at any time during the study. Postoperative medication was intramuscular meperidine, $50 \mathrm{mg}$ in control patients and $25 \mathrm{mg}$ in Group $A$ and $B$ patients.

Before induction of anaesthesia, a central venous pressure catheter was inserted via the right internal jugular vein for blood sampling. A Foley catheter was also inserted. All transplant patients were hacmodialyzed at least twelve hours before the operation and the serum electrolytes were within normal limits. All patients in the study had normal liver function tests preoperatively. Renal function. after transplantation was assessed by renal scintigraphy and by determining serum creatinine and electrolyte levels.

Induction of anaesthesia consisted of intravenous thiopentone $3 \mathrm{mg} \cdot \mathrm{kg}^{-1}$, and pancuronium $0.1 \mathrm{mg}$. $\mathrm{kg}^{-1}$ followed by tracheal intubation. Anaesthesia was maintained with nitrous oxide-oxygen 50 per cent and halothane. Ventilation was controlled using an Air Shields ventilator set to deliver a tidal volume of $10 \mathrm{ml} \cdot \mathrm{kg}^{-1}$ a rate of $10 \cdot$ minute ${ }^{-1}$. Urine and blood samples were collected before, and at 15 minutes, 12 hours and 24 hours after the end of anaesthesia. A scoring system was used to assess the level of consciousness, with 10 the highest. possible score and 3 the lowest using three parameters: eye opening, response to verbal stimuli, and response to pain. Assessment of the level of the consciousncss was performed by an anaesthesiologist blinded to the treatment group, using the following scoring point system: (a) Eye opening none 1 , to pain 2 , to command 3 , and spontaneous 4. (b) Level of consciousness - nonresponsive 1 , confused 2, and obeying commands 3. (c) Response to pain - response only to deep pain 1 , response to superficial stimulus 2, and complaint of pain 3 .

Anaesthetic exposure is expressed as the inspired concentration multiplied by the duration of administration in hours. Halothane dose was estimated by recording inspired concentrations every 15 minutes, using a Narkomed analyzer.

Bromide levels were measured using a digital ion analyzer with a specific bromide electrode and reference calomel electrode. Blood samples were centrifuged to separate red cells from plasma and refrigerated until bromide concentration was measurcd. Morphine levels were measured by liquid chromatography and results were expressed in $\mu \mathrm{g} \cdot 100 \mathrm{ml}^{-1}$. Statistical analysis within each group was done using a Student's t test for paired data and results are expressed as mean $\pm \mathrm{SE}$. A p value $<$ 0.025 was considered significant.

Statistical analysis between the different groups was performed using a multiple range test (Modified LSD Procedure).

\section{Results}

There was no difference in serum bromide levels between Group A and B patients. Serum and urine bromide levels were significantly increased in Groups $A$ and $B$ in comparison with the control group, 15 minutes after the operation, and $: 2$ and 24 hours later (Table I). There were no significant differences in urine bromide levels between Groups $A$ and $B$ and the control group early after the operation and twenty-four hours later.

Morphine levels were increased significantly in Group $B$ patients from control after the operation, 12 , and 24 hours later. Levels increased to $50 \pm$ $4.05 \mu \mathrm{g} \cdot 100 \mathrm{ml}^{-1}$ just before anaesthesia, reaching a peak level of $145=29.5 \mu \mathrm{g} \cdot 100 \mathrm{ml}^{-1}$ five minutes after the operation. Twelve and 24 hours later the morphine levels were $70 \pm 17.75$ ( $p<$ $0.025)$ and $15 \pm 0.9 \mu \mathrm{g} \cdot 100 \mathrm{ml}^{-1}(\mathrm{p}<0.2)$ respectively. Those values were higher than those found in the control group (Table I).

Serum and urine electrolytes remained within normal limits. As would be expected, significant increases in urine output occurred in the transplant patients soon after the operation (Table II).

All patients in the control group received postoperative medication. Three patients in Group $A$ and one in Group B received $25 \mathrm{mg}$ of meperidine intramuscularly six hours after the operation. 
TABLE I Bromide levels

\begin{tabular}{|c|c|c|c|c|c|}
\hline & & Before operation & After operation & 12 hours & 24 hours \\
\hline $\begin{array}{l}\text { Serum bromide } \\
\left(\mu \mathrm{g} \cdot \mathrm{ml}^{-1}\right)\end{array}$ & $\begin{array}{l}\text { A } \\
\text { B } \\
\text { C }\end{array}$ & $\begin{array}{r}45 \pm 1.16 \\
45.9 \pm 1.20 \\
42.5 \pm 1.45\end{array}$ & $\begin{array}{c}60.5 \pm 2.75^{*} \\
60 \pm 2.90^{*} \\
50 \pm 2.00^{*} \mathrm{~g}\end{array}$ & $\begin{array}{c}99.75 \pm 10.5^{*} \\
92.5 \pm 9.25^{*} \\
68.75 \pm 4.75^{*} \mathrm{8}\end{array}$ & $\begin{array}{l}145 \pm 20.5^{*} \\
158 \pm 20.0^{*} \\
95 \pm 8.75^{* 8}\end{array}$ \\
\hline $\begin{array}{l}\text { Serum norphine } \\
\left(\mu \mathrm{g} \cdot 100 \mathrm{ml}^{-1}\right)\end{array}$ & $\begin{array}{l}\text { A } \\
\text { B } \\
\text { C }\end{array}$ & $\begin{array}{l}- \\
50 \pm 4.05 \\
35 \pm 2.75\end{array}$ & $\begin{array}{c}- \\
145 \pm 29.5^{*} \mathrm{~s} \\
5 \pm 1.05^{*}\end{array}$ & $\begin{array}{c}-70 \pm 17.75 * 8 \\
1 \pm 0.75\end{array}$ & $\begin{aligned} 15 & =0.908 \\
0.75 & =0.22\end{aligned}$ \\
\hline $\begin{array}{l}\text { Urine bromide } \\
\qquad\left(\mu g \cdot \mathrm{ml}^{-1}\right)\end{array}$ & $\begin{array}{l}\text { A } \\
\text { B } \\
\text { C }\end{array}$ & - & $\begin{array}{l}0.54 \pm 0.10^{*} \\
0.56 \pm 0.09^{*} \\
0.50 \pm 0.15\end{array}$ & $\begin{array}{l}0.63 \pm 0.03^{*} \\
0.60 \pm 0.02^{*} \\
0.94 \pm 0.25^{*}\end{array}$ & $\begin{array}{l}0.80=0.30 \\
0.75 \pm 0.25 \\
0.57 \pm 0.20\end{array}$ \\
\hline $\begin{array}{l}\text { Awakening time } \\
\text { score }\end{array}$ & $\begin{array}{l}\text { A } \\
\text { B } \\
\text { C }\end{array}$ & - & $\begin{array}{c}6.5 \pm 0.5 \\
4 \pm 0.35 \\
9 \pm 0.558\end{array}$ & $\begin{array}{l}9 \pm 0.95^{*} \\
7 \pm 0.75^{*} \S \\
10 \pm 1\end{array}$ & $\begin{array}{c}10 \pm 0.97 \\
9 \pm 0.90^{*} \\
10 \pm 1\end{array}$ \\
\hline
\end{tabular}

All values are expressed as mean $\pm \mathrm{SE}$.

* $\mathrm{p}<0.025$ for significance within each group.

$\$$ for significance between the different groups.

$\left.\begin{array}{l}\text { Group A - no preoperative medication } \\ \text { Group } \mathrm{B} \text { - preoperative medication }\end{array}\right\}$ Renal transplant pacients.

Group B - preoperat

Assessment score points for the level of consciousness were $6.5 \pm 0.5$ in Group A soon after the operation, $9 \pm 0.95(p<0.025)$ and $10 \pm 0.97(p<$ 0.025 ) 12 and 24 hours later. Group B had an assessment score of $4 \pm 0.35$ after the operation and $7 \pm 0.75(\mathrm{p}<0.025)$ and $9 \pm 0.9(\mathrm{p}<0.02) 12$ and 24 hours later. Group $C$ patients had a score of $9 \pm$ 0.55 soon after the operation and $10 \pm 112$ and 24 hours later (Table I).

There was no difference in the duration of anaesthesia between the groups (Group $\mathrm{A}-207 \pm$ 10 min; Group B - $203 \pm 11$ min; Group C $-210 \pm$ $15 \mathrm{~min}$ ); anaesthetic exposure (inspired concentration $\times$ hours) was $2.25 \pm 0.12$ in Group A, $2.10 \pm$ 0.15 in Group B, and $3.65 \pm 0.4$ in Group C.

\section{Discussion}

Was bromide responsible for the prolonged sleepdiness in our patients?

Bromide produces many CNS effects, including somnolence and confusion. These symptoms ordinarily persist for 12 to 14 days - the plasma half-life of bromide. ${ }^{9}$ Bromide depends on the kidney for its excretion and significantly increased levels were found in the postoperative kidney transplant patients. It is well known that the newly transplanted kidney ideally secretes urine soon after the clamp is removed, but since selective function of the kidney is not present until 12 to 24 hours after transplantation, it may take some time before the osmolality of the urine is normal. Only 30 per cent of our transplant patients had normal kidney function, as determined by renal scintigraphy, eight hours after the operation. This technique provides a simple, rapid, and accurate method of evaluating renal function after kidney transplantation. ${ }^{10}$

Abnormal electrolytes, such as hypochloraemia, can slow bromide excretion, but our patients had electrolytes within normal limits. We cannot explain the prolonged sleeping times in Group A and $B$ patients by the bromide concentrations measured since concentrations in excess of $480 \mu \mathrm{g} \cdot \mathrm{ml}^{-1}$ are necessary for bromism. Group $C$ patients had higher awakening scores than Groups $A$ and $B$ even when they had higher bromide levels and had received $10 \mathrm{mg}$ of morphine as preoperative medication. Blood urea nitrogen and creatinine were also near normal in the first postoperative hours in both groups which appears to discount the theory that increased levels of metabolic products are responsible for the slow responsiveness of these patients. Since there was no significant difference in serum bromide levels between Groups $A$ and $B$ and Group A patients had a better response score soon after operation and 12 hours later, residual anaesthetics alone cannot explain this occurrence. 
TABLE II Urine output and electrolytes before and after operation

\begin{tabular}{llcccc}
\hline & & $\begin{array}{l}\text { Sodium } \\
(m E q / l)\end{array}$ & $\begin{array}{l}\text { Pofassium } \\
(m E q / l)\end{array}$ & $\begin{array}{l}\text { Chloride } \\
(\mathrm{mEq} / \mathrm{l})\end{array}$ & $\begin{array}{l}\text { Urine output } \\
\text { (cc/hour })\end{array}$ \\
\hline $\mathrm{A}$ & $(1)$ & $79.5 \pm 6.95$ & $25.3 \pm 3.5$ & $82.5 \pm 9$ & $15 \pm 2.5$ \\
& $(2)$ & $70 \pm 5.75$ & $30 \pm 3$ & $65.5 \pm 7$ & $109 \pm 8.9^{*}$ \\
$\mathrm{~B}$ & $(1)$ & $84 \pm 10.5$ & $21.5 \pm 2.5$ & $9 \pm 9.5$ & $12 \pm 3.4$ \\
& $(2)$ & $75 \pm 9.70$ & $25 \pm 2.75$ & $76 \pm 8$ & $96.5 \pm 11.5 *$ \\
$\mathrm{C}$ & $(1)$ & $60 \pm 8.5 \$$ & $34 \pm 4.5 \$$ & $100 \pm 9.5 \S$ & $72 \pm 8.5 \$$ \\
& $(2)$ & $57.5 \pm 7 \S$ & $39.5 \pm 5.5 \$$ & $97.5 \pm 8 \S$ & $85 \pm 10.5 \S$ \\
\hline
\end{tabular}

1 - before operation.

2 - 12 hours after operation.

All values expressed as mean \pm SE.

${ }^{*} \mathrm{p}<0.025$ for significant difference within group.

$\S$ for significance between the different groups.

For many years, it has been realized that the binding of drugs to components in the blood and tissues including protein can profoundly influence not only the pharmacodynamics and toxicologic actions of drugs but also their disposition.

Almost every drug exerts its pharmacologic effect by interacting with some kind of protein in the body and eliminated from the body principally by combining with a transport system or drug metabolizing enzyme.

Morphine is mainly metabolized by glucuronation in the liver, methylation to codeine, or demethylation to normophine which is a more potent CNS depressant than morphine. Free morphine molecule excretion by the urine accuunts only for ten per cent of the total administered because of redistribution, accumulation of parenchymatous organs, and biotransformation.

Experimental data have revealed a significant decrease of the albumin fraction of the plasma protein after nephrectomy and increased sensitivity to intravenous barbiturate.

Previous studies have shown a decreased protein binding in plasma ${ }^{11}$ from patients with acute renal failure, due to damaged or incompletely synthesized proteins, lower plasma protein concentrations, and accumulation of compounds which also have affinity for the drug binding sites on the proteins. Morphine is bound to plasma albumin. Decreases in albumin level, as seen in azotemic patients, ${ }^{12}$ can increase the amount of free drug, thereby causing prolongation of its pharmacological effect and increase of the rate of penetration of the free drug into the brain. That might explain the higher blood morphine levels found in these patients soon after transplantation. Twenty-four hours later the values were lower than the preoperative values. Since bromide values at that time were higher than in the preoperative pe: $\backslash$ d, the perfect response score found suggests th. morphine metabolites might be responsible for the prolonged recovery of consciousness in the postoperative period

Morphine metabolites are mainly excreted by the kidney. In the presence of nonfunctioning kidneys, increasing concentrations of morphine derivatives can be found in the circulation, resulting in prolonged CNS depression. ${ }^{13}$ The morphine level was higher in Group B than in the control group. Naloxone, administered eight hours after surgery to three patients, of the same characteristics as patients in Group B, but not included in the study, resulced in increasing the score to a perfect ten lasting 45 minutes.

However, the distribution of drugs depends also on other factors such as liquid solubility and blood brain barrier. The blood brain barrier selectively controls the concentration gradients of solutes between the brain and its surrounding environment. Freeman et al. have demonstrated an increase in permeability of the blood brain barrier in uraemia. ${ }^{14}$ They have shown a breakdown in the mechanism which controls the concentration gradients for bromide between the cerebrospinal fluid (CSF) and blood. Higher bromide levels in the brain can directly depress the CNS in patients with end-stage renal failure, resulting in prolonged sleepiness. 
Although the primary site of action of morphine is in the CNS in humans, the blood brain barrier tends to impede its entry into the brain. The abnormal blood brain barrier found in those patients may facilitate the accumulation of morphine and its metabolic products in the grey matter resulting in profound respiratory depression. Uraemic patients have decreased cerebral metabolism as indicated by abnormal slow waves on the EEG and decreased oxygen. consumption by the brain.

\section{Conclusion}

Bromide levels in patients who have undergone kidney transplants are higher than values previously reported in patients with normal kidneys. However, they do not approach those described as being associated with CNS depression and were not high enough in our patients to explain their slow awakening following anaesthesia. Most were fully awake after 24 hours, despite bromide blood concentration of $158 \mu \mathrm{g} \cdot \mathrm{ml}^{-1}$. Preoperative medication might, in part, explain this delay since higher values of morphine were found in our control patients compared with values previously reported in patients with normal kidncy function given equal amounts of morphine. Delayed elimination of morphine metabolites, due to nonfunctioning kidneys, might also explain this phenomenon.

Low protein binding due to a decrease of albumin levels and abnormal blood brain barrier due to uraemia can also make more free drug available and facilitate the passage of bromide and morphine or its metabolites to the CNS causing prolonged sleepiness in the postoperative period.

\section{Acknowledgement}

We thank Ms. Wilma Rivera for assistance with manuscript preparation

\section{References}

1 Rehder $K$, Forbes J, Alter $H$. Halothane biotransformation in man: a quantitative study. Anesthesiology 1967; $28: 711-5$.

2 Tinker $J H$, Gandolfi $A J$, Van Dyke RA. Elevation of plasma bromide levels in patients following halothane anesthesia. Time correlation with total halothane dosage. Anesthesiology 1976; 44: 194-6.

3 Arallah $M M$, Geddes $I C$. Metabolism of halothane during and after anaesthesia in man. $\mathrm{Br} J$ Anaesth 1973; 45: 464-9.

4 Waldir M, Pedersoli DVM. Serum bromide concentrations during and after halothane anesthesia in dogs. Am J Vet Res 1980; 41: 77-80.

5 Cohen EN, Trudell $J R$, Edmunds $H N$, Urinary metabolites of halothane in man. Ancsthesiology $1975 ; 43: 392-401$.

6 Johnstone RE, Andrews $R$, Brummond W. Bromide concentrations of anesthetists. Anesthesiology 197.5; 43: $128-32$

7 Johnstone RE, Kennell EM, Behar MG. Increased serum bromide concentration after halothane anesthesia in man. Anesthesiology 1975; 42: 598-601.

8 Duvaldestin P, Mazze RI, Hazebrouck J et al. Halothane biotransformation in anesthetics. Anesthesiology $1979 ; 51: 41-6$.

9 Soremark $R$. The biological half-life of bromide ions in human blood. Acta Physiol Scand 1960; 50: 119-23.

10 Dierhelm AG, Dubovsky EV, Whelchel JD, Hartiey $M W$, Tauxe $W N$. Diagnosis of impaired renal functions after kidney transplantation using renal seintigraphy, renal plasma flow and urinary excretion of Hippurate. Ann Surg 1979; 5: 604-16.

11 Andersen $F$. Protein binding of drugs in plasma from patients with acute renal failure. Acta Pharmacol Toxicol 1973; 32: 417-29.

12 Dundee $J W$, Richards $R K$. Effect of azotemia upon the action of intravenous barbiturate anesthesia. Anesthesiology 1954; 15: 333-46.

13 Mostert JW, Evers JL, Hobika GH, Moore RH, Ambrus $J L$. Cardiorespiratory effects of anaesthesia with morphine or fentanyl in chronic renal failure and cerebral toxicity after morphine. Br $\mathbf{J}$ Anaesth 1971; 143: 1053-9.

14 Freeman RB, Sheff MF, Maher JF et al. The bloodcerebrospinal fluid in uremia. Ann Int Med 1962; 56 : 233-40. 


\section{Résumé}

Les taux de bromure et de morphine et le temps de réveil post-opératoire ont été observés chez 24 patients parmi lesquels 16 devaient subir une transplantation rénale sous anesthésie à l'halothane. Huit d'entre eux (Groupe A) n'avaient reçu aucurte prémédication alors que $10 \mathrm{mg}$ de morphine avait été administrée aux huit autres patients (Groupe B) 60 min avant l'anesthésie. Les huit patients resuants présentant une fonction rénale normale étaient préparés pour une résection du colon (Groupe C cortróle). La quantité de bromure retrouvée chez les transplantés s'est révélée supérieure à celle du groupe contrôle. Les patients du groupe A qui n'avaient reçu aucune prémédication ont eu un réveil plus rapide que ceux du Groupe $B$ dont le taux de morphine à la fin de l'anesthésie était de $145 \mu \mathrm{g} 100 \mathrm{ml}^{-1}$ (tanx beaucoup plus élevé que celui trouvé chez les patients du Groupe C). Les patients qui ont subi la transplantation après prémédication à la morphine n'étaient complètement réveillés qu'après 24 heures malgré un taux de bromure estimé seulement à $158 \mu \mathrm{g} \cdot \mathrm{ml}^{-1}$. Les patients du Groupe $C$ qui ont aussi reçu $10 \mathrm{mg}$ de morphine se sont réveillés beaucoup pius tot que ceux des devx autres groupes.

Il est a noter que le taux de bromure retrouvé s'est révélé nettement inférieur aux $480 \mu \mathrm{g} \cdot \mathrm{ml}^{-1}$ nécessaires pour produire les symptômes du bromisme. Donc le bromure par liui seul n'est pas suffisant pour expliquer le sommeit prolongé chez les patients qui ont subi la transplantation rénale. Une baisse de protéine liée, une baisse du takx d'albumine, une anomalie de la barrière sanguine et du fonctionnement du cerveau, l'administration de morphine avant lopérasion et le degré de fonctionnement du rein transplanté sont d'autres facteurs responsables du sommeil prolongé des patients après. transplansation rénale. 